\title{
Desain dan Pemodelan Maximum Power Point Tracking Menggunakan ANFIS pada Sistem Photovoltaic dengan Buckboost Converter
}

\author{
Abil Huda \\ Teknik Elektro, Fakultas Teknik, Universitas Borneo Tarakan \\ E-mail: abil@engineer.com \\ Patria Julianto \\ Teknik Elektro, Fakultas Teknik, Universitas Borneo Tarakan \\ E-mail: Patria81@gmail.com

\section{Abstrak}

Kebutuhan energi listrik semakin hari semakin meningkat. Bahan bakar fosil seperti batu bara, gas dan minyak bumi merupakan energi yang tidak dapat diperbaharui serta memiliki jumlah yang terbatas. Hal itu mendorong berkembangnya energi terbarukan sebagai sumber energi alternatif pembangkit tenaga listrik. Salah satu sumber energi terbarukan adalah sel surya atau photovoltaic (PV) yang memanfaatkan energi cahaya matahari. Permasalahan dalam penggunaan PV saat ini adalah efisiensinya yang masih rendah dengan biaya yang tinggi. Efisiensi PV dapat ditingkatkan menggunakan metode Maximum Power Point Tracking (MPPT) untuk menghasilkan daya maksimum PV. Penelitian tentang MPPT dilakukan dengan berbagai metode pada aplikasi sistem PV menggunakan Buckboost converter. Penelitian ini menggunakan Adaptive Neuro Fuzzy Inference System (ANFIS) sebagai MPPT untuk menjejak titik daya maksimum. Hasil penelitian menunjukkan bahwa ANFIS mampu bekerja sebagai MPPT dan memiliki respon yang baik dalam menjejak titik daya maksimum diberbagai kondisi iradiasi dan temperatur. PV menghasilkan daya maksimum saat temeperatur tetap dengan variasi iradiasi $400 \mathrm{~W} / \mathrm{m}^{2}, 600 \mathrm{~W} / \mathrm{m}^{2}, 800 \mathrm{~W} / \mathrm{m}^{2}$ dan 1000 $\mathrm{W} / \mathrm{m}^{2}$. PV juga menghasilkan daya maksimum saat iradiasi tetap dengan variasi temperatur $15^{\circ} \mathrm{C}, 25^{\circ} \mathrm{C}$ dan $40^{\circ} \mathrm{C}$.

Kata Kunci: ANFIS, Buckboost, MPPT, Photovoltaic.

\section{Abstract}

The need for electric energy is increasing every day. Fossil fuels such as coal, gas and petroleum are nonrenewable energy and have a limited amount. It encourages the development of renewable energy as an alternative energy source of electricity. One renewable energy source is a solar cell or photovoltaic (PV) that utilizes solar light energy. The problem with current PV usage is its low efficiency with high cost. The PV efficiency can be improved using the Maximum Power Point Tracking (MPPT) method to generate maximum PV power. Research on MPPT/is done by various methods on PV system application using Buckboost converter. This research uses Adaptive Neuro Fuzzy Inference System (ANFIS) as MPPT to track maximum power point. The results show that ANFIS is able to work as MPPT and has a good response in tracking the maximum power point in various irradiation and temperature conditions. PV produces maximum power during fixed temperature with irradiation variations of $400 \mathrm{~W} / \mathrm{m}^{2}, 600 \mathrm{~W} / \mathrm{m}^{2}$, $800 \mathrm{~W} / \mathrm{m}^{2}$ and $1000 \mathrm{~W} / \mathrm{m}^{2}$. PV also produces maximum power when irradiation is fixed with temperature variations $15^{\circ} \mathrm{C}, 25^{\circ} \mathrm{C}$ and $40^{\circ} \mathrm{C}$.

Keywords: ANFIS, Buckboost, MPPT, Photovoltaic

\section{PENDAHULUAN}

Saat ini bahan bakar fosil berupa minyak bumi dan batu-bara masih menjadi sumber energi yang paling banyak digunakan dalam proses pembangkitan tenaga listrik. Bahan bakar fosil tersebut tidak dapat diperbarui dan jumlahnya semakin menipis seiring dengan berjalannya waktu. Karena kebutuhan energi listrik semakin hari semakin meningkat, kebutuhan sumber energi alternatif terutama sumber energi terbarukan menjadi sangat tinggi dalam beberapa tahun terakhir (Sankarganesh dan Thangvel, 2012: 429).

Salah satu sumber energi terbarukan adalah Photovoltaic (PV) yang merupakan sumber energi yang memanfaatkan energi cahaya matahari. Sumber energi ini memiliki kelebihan yaitu bebas polusi dan memiliki ketersediaan yang tak terbatas (Soedibyo dkk 2014:394).

Permasalahan dalam penggunaan PV saat ini adalah efisiensinya yang masih rendah dengan biaya yang tinggi. Kebutuhan penggunaan PV yang semakin meningkat 
mendorong berbagai penelitian mengenai peningkatan efisiensi pada sistem PV. Terdapat tiga faktor yang mempengaruhi efisiensi sistem PV. Pertama adalah material PV. Kedua adalah efisiensi konverter dan ketiga adalah efisiensi algoritma Maximum Power Point Tracking (MPPT) seperti pada penelitian (Devi \& Chilambarasan, 2013:105)

PV dapat memberikan daya output sesuai dengan kapasitas. Kapasitas daya output maksimal PV dapat dihasilkan dengan penggunaan metode Maximum Power Point Tracking (MPPT).

Buckboost converter adalah konverter DC-DC. Konverter ini dapat mempunyai tegangan output lebih besar atau lebih kecil dari tegangan inputnya. Komponen dari rangkaian konverter ini terdiri dari sebuah saklar semikonduktor, dioda, induktor dan kapasitor seperti pada penelitian (Hemalatha dkk, 2014)

Adaptive Neuro Fuzzy Inference System (ANFIS) merupakan metode yang menggunakan jaring syaraf tiruan (Neural Network) untuk mengimplementasikan Fuzzy Inference System (FIS) atau sistem inferensi fuzzy. Keunggulan sistem inferensi fuzzy adalah dapat menerjemahkan pengetahuan dari pakar dalam bentuk aturan-aturan, namun biasanya dibutuhkan waktu yang lama untuk menetapkan fungsi keanggotaannya. Oleh sebab itu dibutuhkan teknik pembelajaran dari jaringan syaraf tiruan untuk mengotomatisasi proses tersebut sehingga dapat mengurangi waktu pencarian, hal tersebut menyebabkan metode ANFIS sangat baik untuk diterapkan pada MPPT (Tarek dkk, 2013)

Tujuan penelitian adalah memperoleh desain Maximum Power Point Tracking menggunakan ANFIS pada Sistem PV dengan Buckboost Converter.

Penelitian ini menggunakan metode ANFIS sebagai MPPT yang mengontrol Buckboost converter pada aplikasi sistem PV. Diharapkan metode ANFIS dapat bekerja sebagai MPPT sehingga PV dapat menghasilkan daya maksimum.

\section{Parameter PV}

Tabel 1. Parameter PV KC200GT

\begin{tabular}{c|cr}
\hline No. & Parameter & \multicolumn{1}{c}{ Nilai } \\
\hline 1. & Impp & $7,7 \mathrm{~A}$ \\
2. & Vmpp & $25,98 \mathrm{~V}$ \\
3. & Pmax & $200 \mathrm{~W}$ \\
4. & Isc & $8,21 \mathrm{~A}$ \\
5. & Voc & $32,9 \mathrm{~V}$ \\
6. & Rp & $415,405 \Omega$ \\
7. & Rs & $0,00684 \Omega$ \\
\hline
\end{tabular}

\section{Parameter Buckboost Converter}

Tabel 2. Desain Buckboost Converter

\begin{tabular}{c|cc}
\hline No. & Parameter & \multicolumn{1}{c}{ Nilai } \\
\hline 1. & Vi & $26 \mathrm{~V}$ \\
2. & Vo & $220 \mathrm{~V}$ \\
3. & $\mathrm{~L}$ & $9 \mathrm{mH}$ \\
4. & $\mathrm{C}$ & $0,012 \mathrm{mF}$ \\
\hline
\end{tabular}

Buckboost converter didesain dengan tegangan input $26 \mathrm{~V}$ dengan tegangan output $220 \mathrm{~V}$.

\section{Adaptive Neuro Fuzzy Inference System}

MPPT adalah metode menjejak titik daya maksimum disetiap kondisi iradiasi matahari dan temperatur. Keluaran ANFIS adalah arus referensi Impp (maximum power point) yang merupakan arus pada titik daya maksimum. Impp akan dieksekusi oleh buckboost converter untuk memastikan PV membangkitkan arus yang sama dengan arus referensi yang dihasilkan oleh ANFIS. Jika PV membangkitkan arus di Impp, maka PV akan menghasilkan daya maksimum.

Masukkan ANFIS adalah iradiasi cahaya matahari dan temperatur. Keluarannya adalah arus referensi berupa Impp. Stuktur ANFIS terdiri dari dua masukkan dengan 7 fungsi keanggotaan segitiga, 49 rule dan 1 keluaran.

\section{METODE}

\section{Rancangan Sistem}
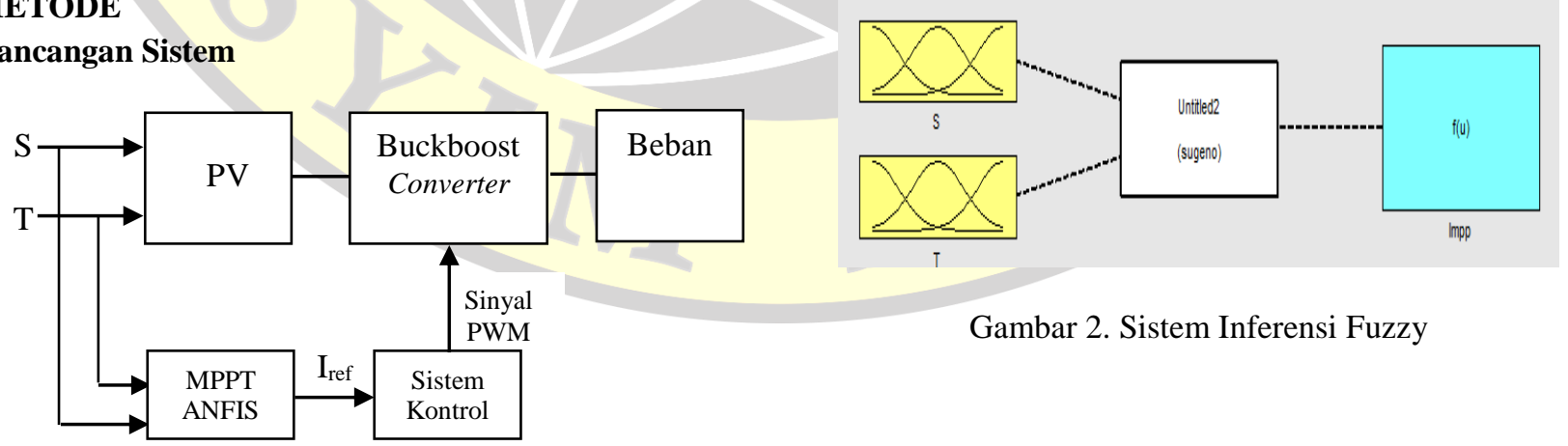

Gambar 1. Desain Sistem 


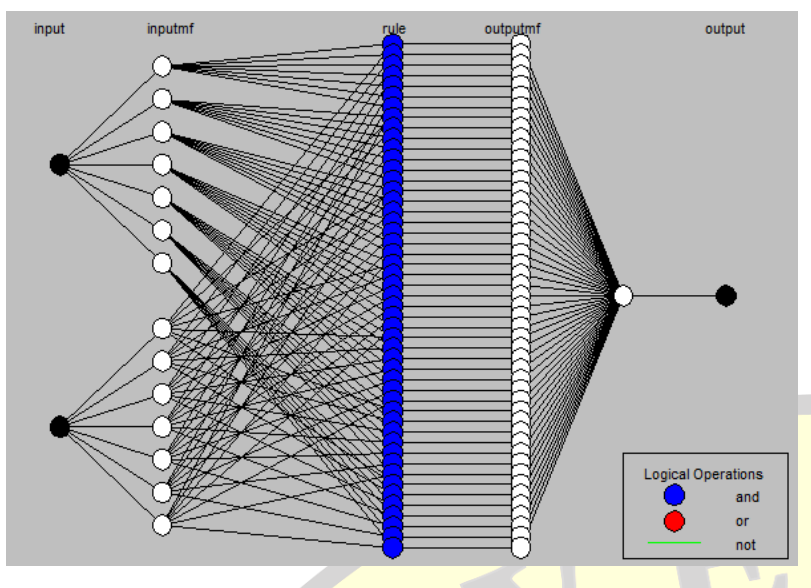

Gambar 3. Struktur ANFIS

Masukkan pertama adalah iradiasi cahaya matahari seperti yang ditunjukkan gambar 4. Masukkan kedua adalah temeratur seperti yang ditunjukkan gambar 5 .

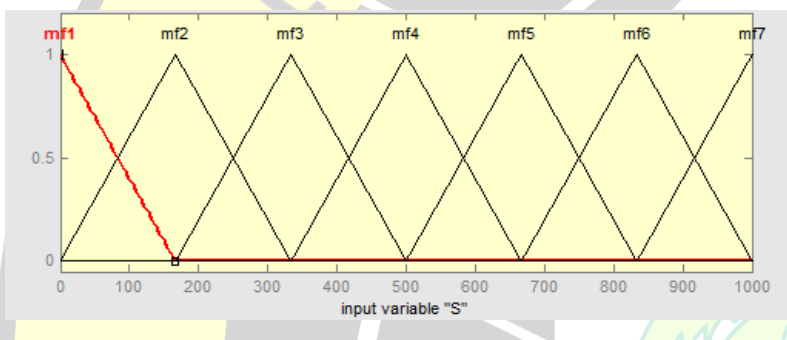

Gambar 4. Fungsi Keanggotaan Iradiasi Matahari

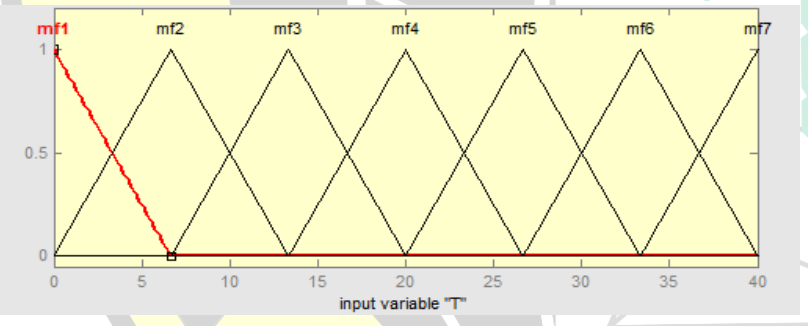

Gambar 5. Fungsi Keanggotaan Temperatur

\section{Sasaran Penelitian}

Sasaran penelitian adalah parameter:

1. Iradiasi Matahari (S)

2. Temperatur (T)

3. Daya Maksimum PV (Ppv)

Iradiasi matahari, temperatur dan daya maksimum PV digunakan untuk menentukan kualitas kerja dari ANFIS sebagai MPPT.

\section{Teknik Pengumpulan Data}

Teknik pengumpulan data dilakukan dengan cara menjalankan simulasi dengan kondisi iradiasi matahari dan temperatur yang bervariasi.

\section{Teknik Analisis Data}

Teknik analisis data dalam penelitian ini dilakukan dengan cara membandingkan daya maksimum PV yang didesain dengan daya maksimum PV hasil simulasi. Semakin kecil eror atau selisih antara daya maksimum PV hasil simulasi dengan daya maksimum PV yang didesain, maka semakin baik respon ANFIS bekerja sebagai MPPT.

\section{HASIL DAN PEMBAHASAN}

Simulasi sistem dilakukan dengan 2 kondisi. Pertama kondisi iradiasi yang bervariasi dengan temperatur tetap. Kedua kondisi iradiasi tetap dengan temperatur bervariasi.

Variasi iradiasi \& temperature tetap

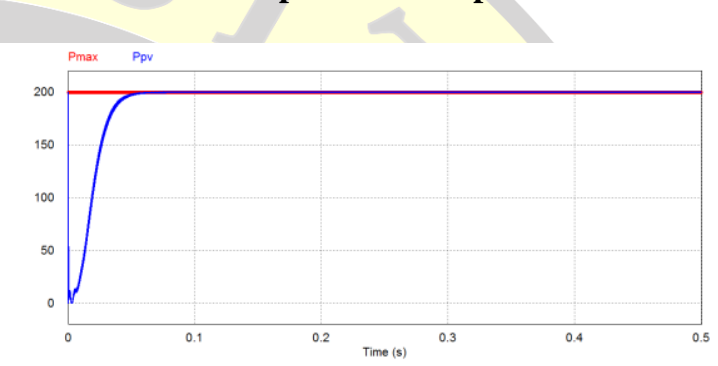

Gambar 6. Ppv $200 \mathrm{~W}$ dengan iradiasi $1000 \mathrm{~W} / \mathrm{m}^{2}$

Gambar 6 menunjukkan bahwa daya yang dihasilkan oleh PV merupakan daya maksimum yang dapat dihasilkan oleh PV ketika diberikan iradiasi $1000 \mathrm{~W} / \mathrm{m}^{2}$ dan temperatur $25^{\circ} \mathrm{C}$. Gambar 7,8 dan 9 juga menunjukkan bahwa daya yang dihasilkan oleh PV merupakan daya maksimum yang dapat dihasilkan oleh PV ketika diberikan iradiasi yang bervariasi. Hal ini menunjukkan kinerja ANFIS sebagai MPPT sasngat baik.

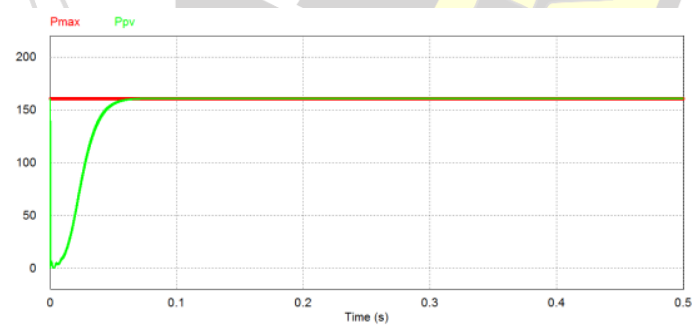

Gambar 7. Ppv $160 \mathrm{~W}$ dengan iradiasi $800 \mathrm{~W} / \mathrm{m}^{2}$

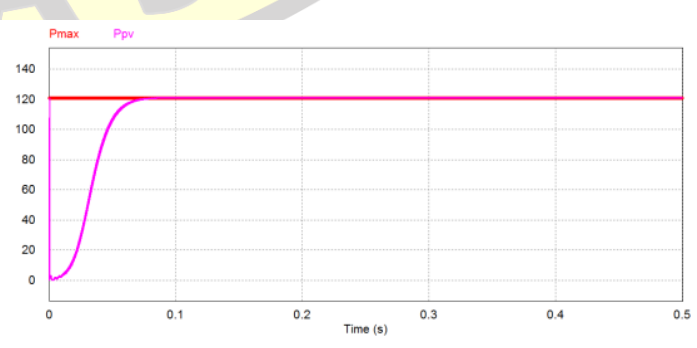

Gambar 8. Ppv $120 \mathrm{~W}$ dengan iradiasi $600 \mathrm{~W} / \mathrm{m}^{2}$ 


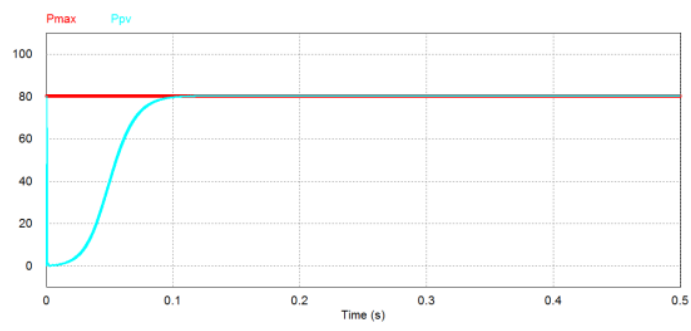

Gambar 9. Ppv $80 \mathrm{~W}$ dengan iradiasi $400 \mathrm{~W} / \mathrm{m}^{2}$

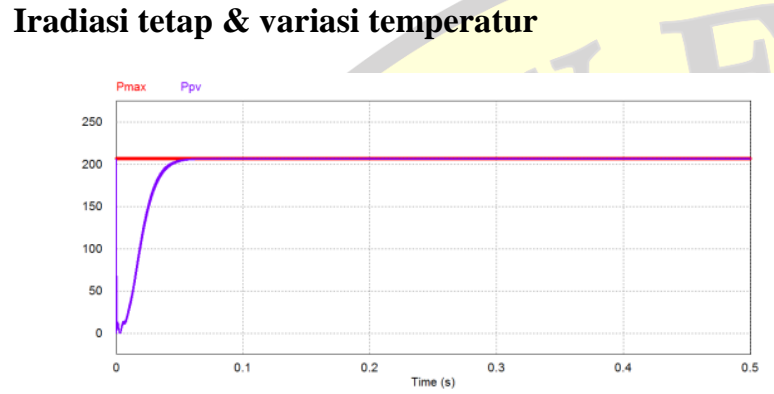

Gambar 10. Ppv $207 \mathrm{~W}$ dengan temperatur $15^{\circ} \mathrm{C}$

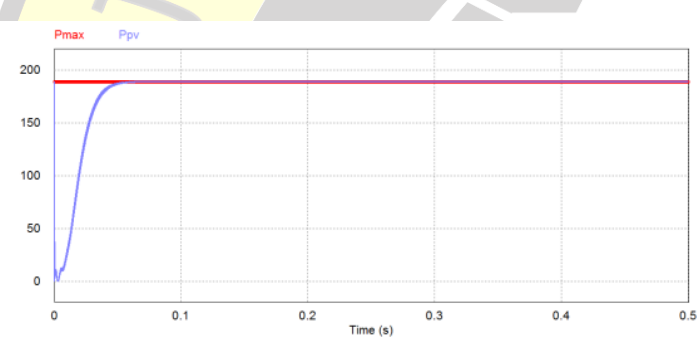

Gambar 11. Ppv $189 \mathrm{~W}$ dengan temperatur $40^{\circ} \mathrm{C}$

Gambar 6. menunjukkan bahwa daya yang dihasilkan oleh PV merupakan daya maksimum yang dapat dihasilkan oleh PV ketika diberikan iradiasi $1000 \mathrm{~W} / \mathrm{m}^{2}$ dan temperatur $25^{\circ} \mathrm{C}$. Gambar 6, 10 dan 11 juga menunjukkan bahwa daya yang dihasilkan oleh PV merupakan daya maksimum yang dapat dihasilkan oleh PV ketika diberikan iradiasi tetap dan temperatur yang bervariasi. Hal ini menunjukkan kinerja ANFIS sebagai MPPT sasngat baik.

\section{PENUTUP}

\section{Simpulan}

Simpulan menyajikan ringkasan dari uraian mengenai hasil dan pembahasan, mengacu pada tujuan penelitian. Berdasarkan kedua hal tersebut dikembangkan pokokpokok pikiran baru yang merupakan esensi dari temuan penelitian.

Berdasarkan hasil analisis dan simulasi, maka diambil kesimpulan sebagai berikut :

1. ANFIS mampu bekerja sebagai MPPT.

2. Kontrol MPPT ANFIS memiliki respon yang baik dalam menjejak titik daya maksimum diberbagai kondisi iradiasi dan temperatur.
3. PV menghasilkan daya maksimum dengan variasi iradiasi.

4. PV menghasilkan daya maksimum dengan variasi temperatur.

\section{Saran}

Berdasarkan hasil analisis dan simulasi, dapat dilakukan penelitian lanjutan sebagai berikut:

1. Sistem dapat dikembangkan dengan menambah sistem penampungan daya PV seperti baterai ataupun on grid.

2. Sistem dapat diaplikasikan sebagai sumber untuk aplikasi kendali motor listrik.

3. Sistem juga dapat diaplikasikan ke dalam bentuk implementasi.

\section{DAFTAR PUSTAKA}

Abil Huda dan Patria Julianto. 2016. Modeling And Simulation Of Maximum Power Point Tracking Using Adaptive Neuro Fuzzy Inference System In Photovoltaic Application With Boost Converter, SALINGDIDIK, pp. 412-421.

Devi, M. L. \& Chilambarasan, M. 2013. Design and Simulation of Incremental Conductance MPPT Using Self Lift Cuk Converter, International Conference on Renewable Energy and Sustainable Energy [ICRESE' $13]$.

Hemalatha, J., N., Dr. Hariprasad, S. A., \& Dr. G. S. Anitha. 2014. Performance Evaluation of Single Ended Primary Conductance Converter for Photo Voltaic Applications, International Converence on Magnetics, Machines \& Drives (AICERA-2014 iCMMD).

Roberto F. Coelho, Walbermark M. dos Santos and Denizar C. Martins. Influence of Power Converters on PV Maximum Power Point Tracking Efficiency, INEP.

Sahu, T. P. \& Dixit, T.V. 2012. Modelling and Analysis of Peturb \& Observe and Incremental Conductance MPPT Algorithm for PV Array Using Cuk Converter, IEEE Student's Conference on Electrical, Electronics and Computer Science. pp. 1-6.

Sankarganesh, R. \& Thangvel, S. 2012. Maximum Power Point Tracking in PV System using Intelligence based $\mathrm{P} \& O$ Technique and Hybrid Cuk Converter, International Conference on Emerging Trends in Science, Engineering and Technology. pp. 429-436.

Soedibyo, Priananda, C. W. \& Haikal, M. A. 2015. Maximum Power Point Tracking Using Root Finding Modified Bisection Algorithm, International Conference on Information Technology, Computer and Electrical Engineering (ICITACEE), pp. 394-399.

Tarek, B., Said, D., \& Benbouzid, M.E.H. 2013. Maximum Power Point Tracking Control for 
Photovoltaic System Using Adaptive Neuro-Fuzzy

"ANFIS", Eight International Cinverence and

Exhibition on Ecological Vehicles and Renewable Energiws (EVER), IEEE.

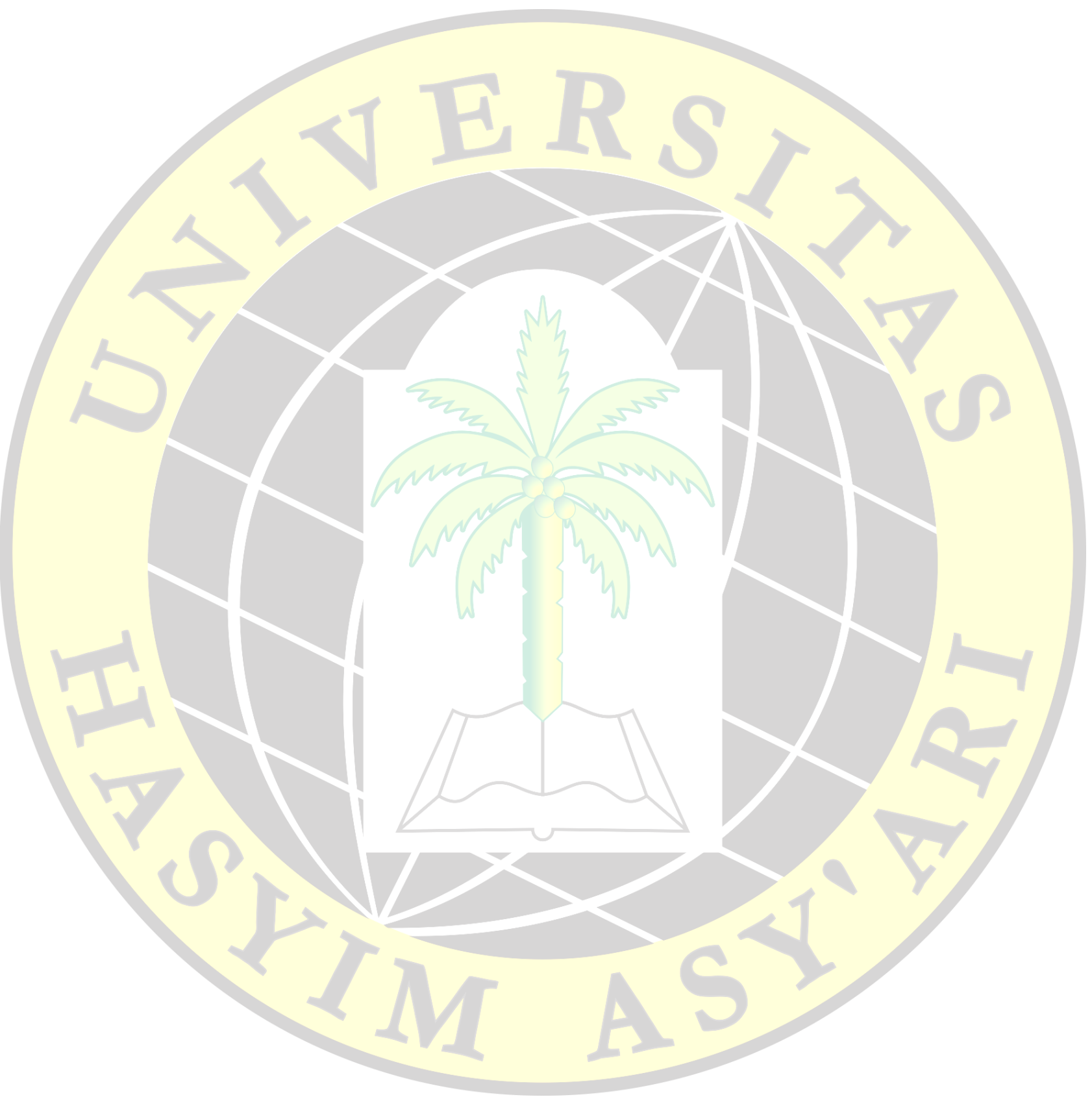

